\title{
Reliable technique of Endoscopic Dacryocystorhinostomy - A Pilot Study
}

\author{
Sudip Kumar Das, ${ }^{1}$ Chiranjib Das, ${ }^{1}$ Amit Bikram Maiti, ${ }^{2}$ Ruma Guha, ${ }^{3}$ Subhendu Chowdhury ${ }^{1}$
}

\begin{abstract}
Introduction
Over last two decades endoscopic dacryocystorhinostomy has gained popularity over external dacryocystorhinostomy for postcanalicular obstruction. But the success rate is not very satisfactory. Our objective is to describe a technique where near $100 \%$ success can be achieved.

Materials and Methods

The study was conducted on 92 patients over 4 years and 6 months. The technique we describe involves creation of a large ostium, creation and apposition of nasal and lacrimal sac mucosal flaps. All the patients were under regular follow-up for 12 months after operation. We also compared our result with other techniques.

Results

The neo-ostium was well healed and free flow of normal saline was seen in 90 cases (97.83\%) post-operatively. In one case there was ostium fibrosis and in another case granulations were seen.

Conclusion

For the past few decades many approaches have been tried for endoscopic dacryocystorhinostomy. But the long term success rates have not been satisfactory. Our technique of creating large stoma and proper mucosal apposition, when done properly gives near $100 \%$ success.

$\underline{\text { Kevwords }}$
\end{abstract}

ABSTRACT

Dacryocystorhinostomy; Endoscopy; Nasal Mucosa; Stents; Mitomycin

$\mathrm{E}$ ndonasal dacryocystorhinostomy was first described in 1893 by Caldwell, but was not commonly performed because of poor visibility and limited access to the endonasal anatomy. ${ }^{1}$ External dacryocystorhinostomy as described in 1904 by Toti, was the procedure of choice for the treatment of postcanalicular stenosis in the 20th century. ${ }^{2}$ But with the advent of nasal endoscopes and relevant instruments there was renewed interest in the endonasal approaches in the early 1990 s. $^{3}$

McDonogh and Meiring described the first modern endonasal dacryocystorhinostomy in $1989 .{ }^{4}$ Over a period of time, success rate varied from $60 \%$ to $90 \%{ }^{5}$ The main cause of failure of dacryocystorhinostomy both external and endoscopic was synechia and granulation formation at the stoma. ${ }^{6}$ Several methods have been tried to improve the patency using canalicular stents and application of mitomycin C. But both stent and mitomycin $\mathrm{C}$ have some disadvantages. Moreover neither of these two techniques gives $100 \%$ success. $^{7} \mathrm{We}$ describe an approach that involves preservation of nasal mucosa and the creation of anterior and posterior flaps of lacrimal sac in order to achieve fusion between nasal mucosa and lacrimal sac thereby bringing the recurrence rate to near zero.

\section{Materials and Methods}

A prospective study comprising of 92 cases was conducted in the Department of Otorhinolaryngology in a district medical college and hospital of West Bengal,

1 - Department of ENT, Bankura Sammilani Medical College, Bankura, West Bengal

2 - Department of ENT, Midnapore Medical College,

Midnapore, West Bengal

3 - Department of ENT, Calcutta National Medical College, Kolkata

Corresponding author:

Dr Chiranjib Das

email: chirubata.das.87@gmail.com 
India, from January 2010 to June 2014.

\section{Preoperative Assessment}

The preoperative evaluation included an ophthalmologic examination with lacrimal duct probing and syringing to determine the site of obstruction. An otorhinolaryngological examination including nasal endoscopy and digital X-ray nose and paranasal sinuses occipitomental view or CT scan whichever needed in particular case, were done to exclude nasal pathology.

\section{Inclusion criteria}

Chronic dacryocystitis, Mucocele of lacrimal sac and Acute on chronic dacryocystitis.

\section{Exclusion criteria}

Epiphora due to entropion or ectropion, Presaccal obstruction, Lacrimal sac tumour, Patients who didn't come for follow-up were excluded from the study.

\section{Surgical Technique}

Nose was prepared with cottonoids soaked in $4 \%$ lidocaine hydrochloride with 1:1000 epinephrine in a ratio of 4:1, 10-15 min prior to surgery. This ensured adequate decongestion, mucosal anaesthesia, easy access and a bloodless field. 2\% lidocaine hydrochloride with 1:100,000 adrenaline was injected submucosally into lateral nasal wall, superior and anterior to the attachment of middle turbinate and then along the maxillary line.

The incision for the mucosal flap begins $5 \mathrm{~mm}$ above the insertion of the middle turbinate and is brought horizontally forward $5 \mathrm{~mm}$ anterior to the middle turbinate. It is taken vertically down to just above the insertion of the inferior turbinate before taking it posteriorly up to the insertion of the uncinate process. (Fig. 1) The mucosal flap is elevated exposing the junction of the hard frontal process of the maxilla and the thin soft lacrimal bone. The lacrimal bone was peeled off the inferior half of the lacrimal sac. Frontal process of the maxilla which overlies the inferior part of the lacrimal sac was removed by straight and upturned Kerrison punch. In the upper part bone becomes too thick to remove by the punch.

As we did not have micro drill, $2 \mathrm{~mm}$ curved osteotome was very useful here. The medial wall of the sac is then tented with a Bowman's probe and incised vertically to create a small anterior and larger posterior flap. Lacrimal syringing was done. Small horizontal cuts are made in these flaps superiorly and inferiorly so that they can be reflected onto the lateral nasal wall without any tension. Once the lacrimal sac flaps have been positioned on the lateral nasal wall the nasal mucosal flap is trimmed into a "C" shape. (Fig. 2) It forms a superior and inferior flap extending anteriorly from the posterior hinge. When reflected back onto the lateral nasal wall the "C" shape of the nasal mucosal flaps fits around the opened lacrimal sac so that the mucosal edges are closely approximated. (Fig. 3) Surgical site was covered with small pieces of absorbable gelatin sponge soaked in Feracrylum solution to hold the flaps in position and to ensure hemostasis. (Fig. 4) Usually,

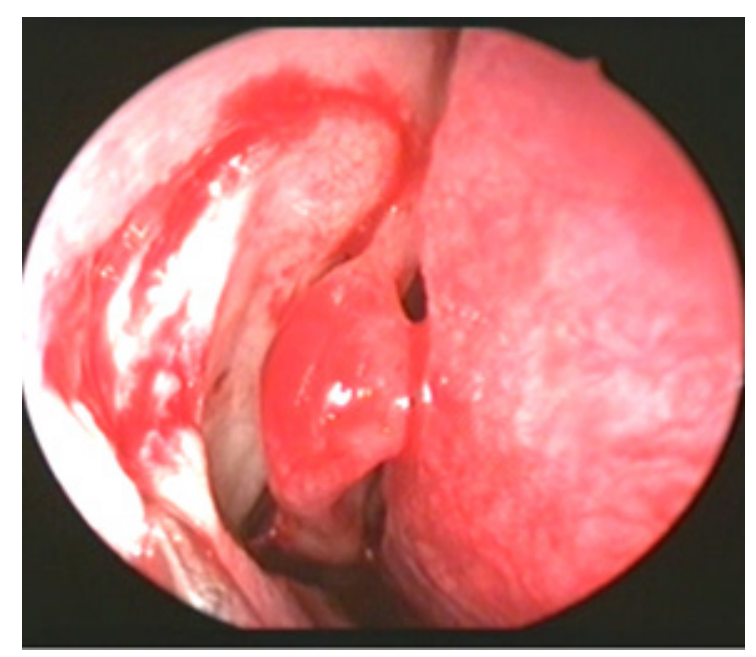

Fig.1 Incision over lateral nasal wall

conventional nasal packing was not done except in 5 cases where apprehension of postoperative bleeding was there.

\section{Postoperative care and follow-up}

Postoperatively, 5 days of oral antibiotics and a topical mixture of antibiotic and steroid eye drops for 1 month were prescribed. Nose drops containing $0.02 \%$ hydrocortisone and $0.025 \%$ naphazoline nitrate was also advised for 2 weeks. Irrigation of the nasal cavity with saline nasal spray was advised to prevent crust formation. It can be easily made at home by mixing 2 pints of common salt and 2 pints of baking soda in 


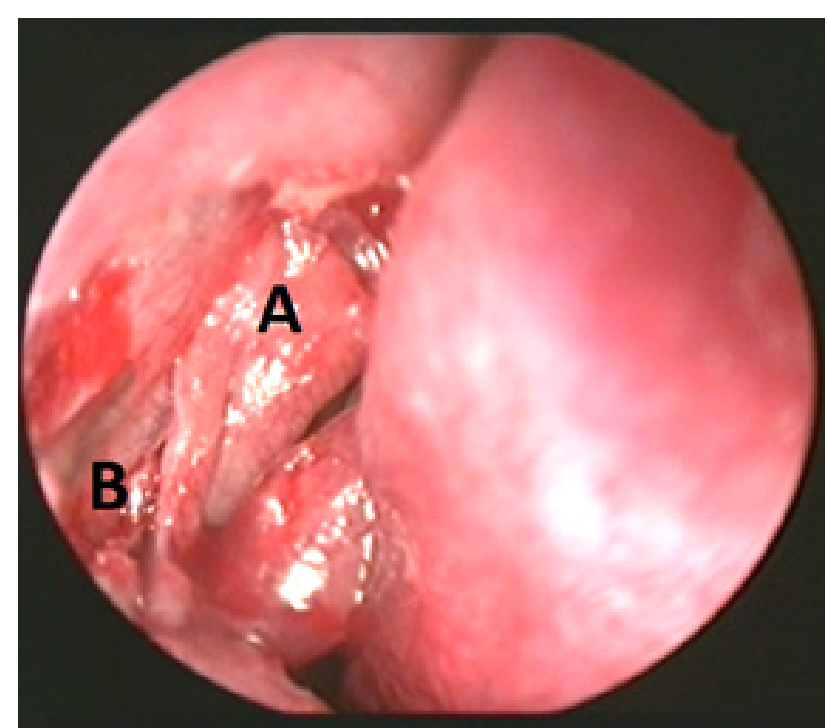

Fig.2 Assessment of nasal mucosal flap (A) to approximate with opened lacrimal sac (B)

$180 \mathrm{ml}$ of boiled water. Follow-up reviews were done 1 week, 2 weeks, 1 month, 3, 6, and 12 months after operation. At each follow-up appointment, a nasal endoscopic examination was performed to assess the wound healing and to remove crusts and granulations if any. Lacrimal irrigation was used to confirm the patency of ostium. Surgical success was defined as absence of epiphora and purulent discharge together with a patent lacrimal system, one year postoperatively.

\section{Results}

Over 4 years we operated on 106 patients. But 14 patients were lost to follow-up. So our study includes 92 patients. Among them 40 were male and 52 were female. Their age ranged from 28 to 64 years. There were 3 cases of revision endoscopic dacryocystorhinostomy. One patient presented with nasolacrimal duct obstruction due to gunshot injury. The neo-ostium was well healed and free flow of water was seen in 90 cases postoperatively. (Fig. 5) In one case there was ostium fibrosis and in another case granulation was seen. In 5 cases synechia was seen between middle turbinate and septum which didn't affect the outcome. So the success rate of our series was $97.83 \%$.

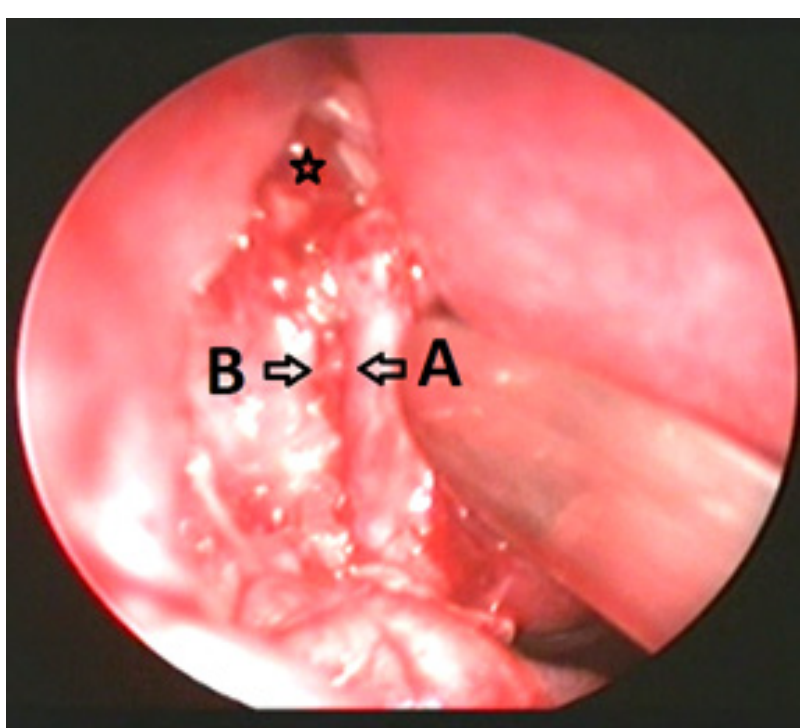

Fig.3 End to end approximation of nasal mucosal flap (A) and posterior flap of lacrimal sac (B). (* = stoma)

\section{Discussion}

Since the early 1990s endoscopic dacryocystorhinostomy has grown in popularity. It has several advantages over external dacryocystorhinostomy like avoiding facial scar, preservation of medial canthal ligament as well as pump action of lacrimal sac. It has minimal morbidity and less risk of intraoperative bleeding. It also enables direct access to the rhinostoma site, reducing tissue injury. Other nasal pathologies like deviated nasal septum or nasal polyp if present can be addressed in the same sitting. It can also be performed during acute dacryocystitis. ${ }^{8}$

The main cause of surgical failure in endoscopic dacryocystorhinostomy is formation of granulation tissues or synechiae at the operative site. ${ }^{6}$ It is more pertinent in Asian patients with a low nasal bridge. This is because that the height and length of the nasal bone has a negative correlation with the thickness of the frontal process of the maxilla. ${ }^{9}$ Nevertheless, creating a large bony ostium requires extensive removal of the frontal process of the maxilla during endoscopic dacryocystorhinostomy. It is therefore inevitable that a portion of the bone at the frontal process of the maxilla will remain exposed at the completion of the operation. So healing occurs by secondary intention. This leads to formation of granulation tissue and scar tissue 


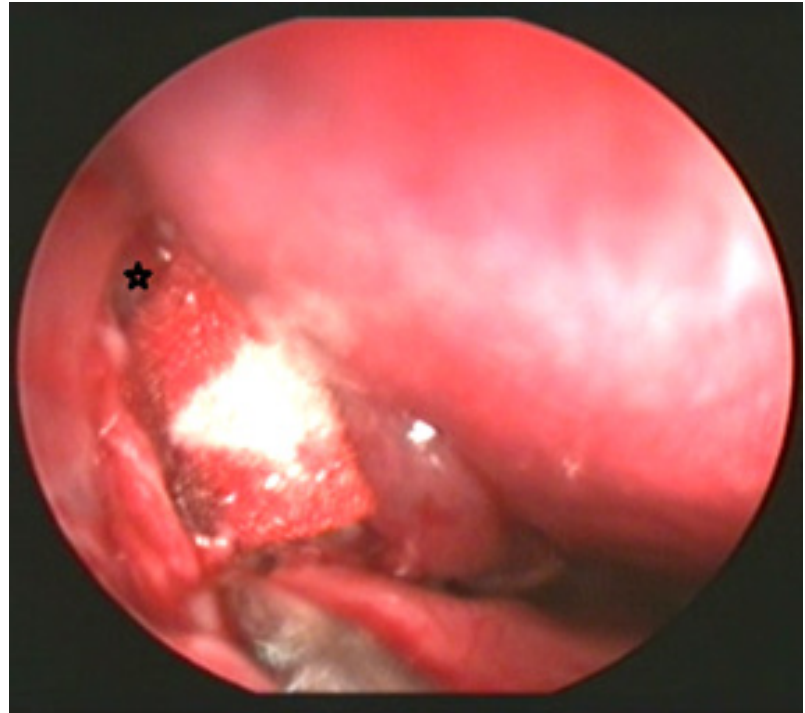

Fig. 4. Absorbable gelatin sponge soaked in Feracrylum placed at the surgical site. $(*=$ stoma $)$

around the ostium, resulting in failure of endoscopic dacryocystorhinostomy. Therefore, it is very important to perform mucosal flap technique to cover bared bone during endoscopic dacryocystorhinostomy for Asian patients. A number of different techniques were used to minimize incidence of granulation tissues or synechiae formation and to improve surgical results. These are use of silicone stents, application of mitomycin C (Table I).

Role of silicone stents in minimizing nasal synechiae is still controversial. Some studies claim good postoperative results by use of stents. Sharma reported a success rate of $88.5 \%$ in his 165 patients using silicon stents. ${ }^{15}$ Sprekelson reported success with endoscopic DCR with stent in $85 \%$ patients. ${ }^{22}$ Kakkar reported 85 to $90 \%$ success with stent and nearly same success rate without stent. 10 Unlu et al reported $85.7 \%$ success rate with use of silicone stents and $87.5 \%$ in patients without stents. ${ }^{23}$ Smirnov et al, in their recent study, have even demonstrated granulation tissue formation due to prolonged use of silicon tubes. So, they recommend to avoid silicon tubes for better post-operative results. ${ }^{24}$ Ray et al found no significant difference in the final outcome with or without stent. They suggested that, silicone stents might help in post-operative clearance of crusts, clots and identification of the inner ostium during endoscopic examination or other endonasal maneuvers, if warranted, during post operative follow up. ${ }^{25}$

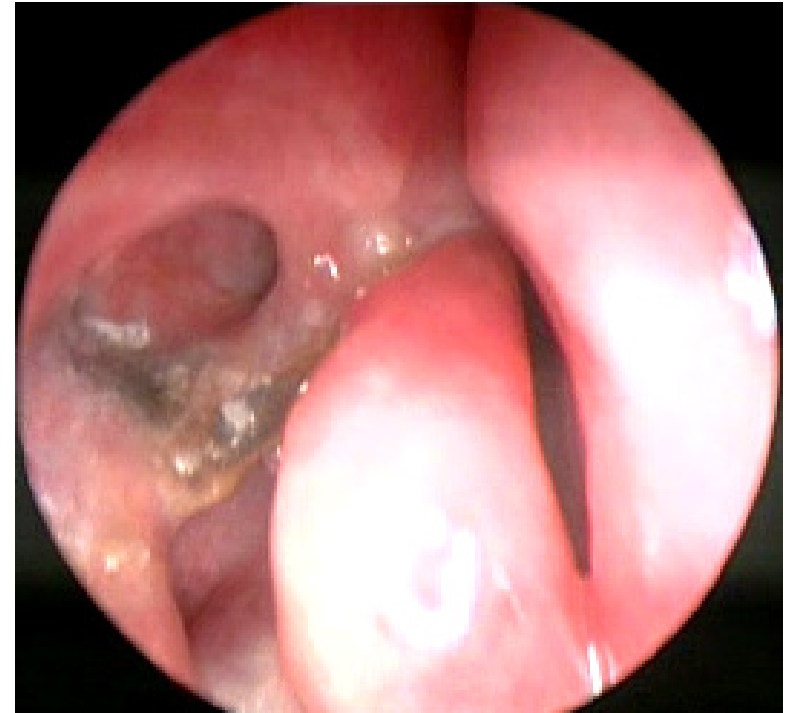

Fig. 5. Ostium 1 month after operation

Jin reported primary success rate of $83 \%$ in endoscopic DCR with stent and in $17 \%$ cases rhinostomy opening was found to be obstructed by granulations or synechia. ${ }^{26}$ Zilelioglu reported lacerations of puncta due to probing and bicanalicular silicon intubation. ${ }^{27} \mathrm{Kim}$ et al reported decreased long-term patency with stents with success rates dropping from 90 to $77 \%{ }^{28}$ Also a major factor negatively affecting patency after stent removal was contraction of lacrimal sac at the time of stent removal. ${ }^{28}$

Mitomycin C, derived from Streptomyces caespitosus, is an alkylating antibiotic. It reduces fibroblast collagen synthesis by inhibiting DNA dependent RNA synthesis and can suppress cellular proliferation in any period of the cell cycle. When used in endoscopic dacryocystorhinostomy, it reduces fibrous adhesion between the osteotomy site and nasal septum and also inhibits scarring around the opening of the common canaliculus. Its effect in glaucoma filtering surgery and pterygium excision has been well established clinically. ${ }^{17}$ Controversy exists regarding the efficacy of adjunctive low dose mitomycin $\mathrm{C}$ during lacrimal surgery for adults with blocked nasolacrimal ducts.

Muhammad Umar Farooq et al demonstrated a 15\% improvement in results using mitomycin C (93.3\%). ${ }^{29}$ But other studies have shown that use of mitomycin $\mathrm{C}$ at the operative site did not improve success rate significantly. Zilelioglu et al found that the success rate 
Table I: Comparison of success rate of different techniques

\begin{tabular}{|c|c|c|c|c|}
\hline TECHNIQUE & AUTHOR & YEAR & $\begin{array}{c}\text { NO. OF } \\
\text { PATIENTS }\end{array}$ & $\begin{array}{c}\text { SUCCESS } \\
\text { RATE }\end{array}$ \\
\hline \multirow{5}{*}{ CONVENTIONAL } & Kakkar et al ${ }^{10}$ & 2008 & 20 & $90 \%$ \\
\hline & Mudhol et al ${ }^{11}$ & 2012 & 30 & $87 \%$ \\
\hline & Naik et al ${ }^{12}$ & 2012 & 172 & $89.53 \%$ \\
\hline & Jain et $\mathrm{al}^{13}$ & 2013 & 30 & $83.33 \%$ \\
\hline & Shah et $\mathrm{al}^{14}$ & 2013 & 39 & $92.30 \%$ \\
\hline \multirow{5}{*}{ SILICON STENTS } & Sharma et al ${ }^{15}$ & 2008 & 165 & $88.5 \%$ \\
\hline & Kakkar et al ${ }^{10}$ & 2008 & 20 & $85 \%$ \\
\hline & Zuercher et $\mathrm{al}^{16}$ & 2011 & 84 & $85.7 \%$ \\
\hline & Naik et al ${ }^{12}$ & 2012 & 66 & $89.39 \%$ \\
\hline & Shah et al ${ }^{14}$ & 2013 & 90 & $93.33 \%$ \\
\hline \multirow{5}{*}{ MITOMYCIN C } & Zilelioglu et $\mathrm{al}^{17}$ & 1998 & 22 & $77.3 \%$ \\
\hline & Ghosh et al ${ }^{18}$ & 2006 & 30 & $80 \%$ \\
\hline & Mudhol et $\mathrm{al}^{11}$ & 2012 & 30 & $97 \%$ \\
\hline & Jain et al ${ }^{13}$ & 2013 & 30 & $90 \%$ \\
\hline & Farooq et al ${ }^{19}$ & 2013 & 82 & $93.3 \%$ \\
\hline \multirow{3}{*}{ MUCOSAL FLAP } & Shan et $\mathrm{al}^{20}$ & 2012 & 120 & $98 \%$ \\
\hline & Sonkhya et $\mathrm{al}^{21}$ & 2008 & 218 & $92 \%$ \\
\hline & Present study & 2014 & 92 & $97.83 \%$ \\
\hline
\end{tabular}

in the mitomycin $\mathrm{C}$ treated group was $77.3 \%$, whereas in the untreated group it was $77.8 \% .{ }^{17}$ Roozitalab et al said that use of intraoperative mitomycin C doesn't change the success rate..$^{30}$ Farahani et al showed that patients with nasolacrimal duct obstruction who underwent endoscopic dacryocystorhinostomy didn't benefit from adjunctive topical application of mitomycin C. ${ }^{31}$ Mitomycin $\mathrm{C}$ induced complications reported in glaucoma filtration or pterygium surgery included dry eye, superficial punctate epitheliopathy, punctal stenosis, corneal and scleral melt, maculopathy, wound infection and leak and endophthalmitis. The optimal dosage and exposure time of mitomycin $\mathrm{C}$ is controversial. ${ }^{31}$

On the contrary, mucosal flap technique is easy, safe and doesn't incur additional costs. Here wound edges are brought together so that they are approximated. It allows the edges of wound to heal by primary intention fairly rapidly. It minimizes scarring. When done perfectly it 
gives near $100 \%$ success. Our study proves it.

\section{Conclusion}

For the past few decades many approaches have been tried for endoscopic dacryocystorhinostomy. But the long term success rates have not been fully satisfactory. The technique we describe involves creation of a large ostium, creation and apposition of nasal and lacrimal sac mucosal flaps. When done properly it gives near $100 \%$ success. The procedure is simple and cost-effective because it does not require sophisticated equipment such as silicone stents or mitomycin C.

\section{References}

1. Toti A. Nuovo método conservatore di cura radicale délie suppurazioni eroniei del sacco lacrimale (daeriocistorinostomia). Clin Med Firenze 1904; 10:38.5-7

2. Caldwell GW. Two new operations for obstruction of the nasal duct. N Y J Med 1893; 57:581-2

3. Ishio K, Sugasawa M, Tayama N, Kaga K. Clinical usefulness of endoscopic intranasal dacryocystorhinostomy. Acta Otolaryngol Suppl. 2007; 559:95-102

4. McDonough M, Meiring JH. Endoscopic transnasaldacryocystorhinostomy. J Laryngol Otol. 1989; 103:585-7

5. Zaidi FH, Symanski S, Olver JM. A clinical trial of endoscopic vs external dacryocystorhinostomy for partial nasolacrimal duct obstruction 2011; 25:1219-24

6. Leong SC, Macewen CJ, White PS. A systematic review of outcomes after dacryocystorhinostomy in adults. Am J Rhinol Allergy 2010; 24:81-90

7. Smimov G, Tuomilehto H, Teräsvirta M, Nuutinen J, Seppä J. Silicone tubing after endoscopie dacryocystorhinostomy: is it necessary? Am J Rhinol. 2006; 20:600-2

8. Hartikainen J, Grenman R, Puukka P, Seppa H. Prospective randomized comparison of external dacryocystorhinostomy and endonasal laser dacryocystorhinostomy. Ophthalmology 1998; 105:1106-13

9. Woo KI, Maeng HS, Kim YD. Characteristics of intranasal structures for endonasal dacryocystorhinostomy in asians. Am J Ophthalmol. 2011; 152(3):491-8 doi: 10.1016/j.ajo.2011.02.019

10. Kakkar V, Chugh J, Sachdeva S, Sharma N, Ramesh. Endoscopic Dacryocystorhinostomy with and without Silicone Stent: A Comparative Study. The Internet Journal of Otorhinolaryngology. 2008 Volume 9 Number 1

11. Mudhol RR, Zingade ND, Mudhol RS, Das A. (2012) Endoscopic Ostium Assessment Following Endonasal
Dacryocystorhinostomy with Mitomycin C Application. Al Ameen J Med Sci. 2012; 5:320-4

12. Naik SM, Mushannavar AS et al. Endonasal dacrocystorhinostomy done with and without silicon stents-A comparative case series analysis study. Int J Head Neck Surg. 2012; 3(3): 147-53

13. Jain NK, Vashistha S, Kaushik S. Comparative Study of Endonasal Endoscopic Dacryorhinostomy with or without Intraoperative Mitomycin C. Clin Rhinol An Int J. 2013; 6(2):77-9

14. Shah H, Sharma $\mathrm{S}$ et al. Comparison of surgical outcome in endoscopic dacrocystorhinostomy with and without silicon stent placement. Nat J Med Res. 2013; 3(1):34-7

15. Sharma BR. Non endoscopic endonasal dacryocystorhinostomy versus external dacryocystorhinostomy. Kathmandu Univ Med J. 2008; 6:437-42

16. Zuercher B, Tritten JJ, Friedrich JP, Monnier P. Analysis of functional and anatomic success following endonasal dacryocystorhinostomy. Ann Otol Rhinol Laryngol. 2011;120:231-8

17. Zilelioglu G, Ugurbas SH, Anadolu Y et al. Adjunctive use of mitomycin $\mathrm{C}$ on endoscopic lacrimal surgery. $\mathrm{Br} \mathrm{J}$ Ophthalmol. 1998; 82: 63-66

18. Ghosh S, Roychoudhury A, Roychaudhuri BK (2006) Use of mitomycin C in endo-DCR. Indian J Otolaryngol Head Neck Surg. 58: 368-9

19. Farooq MU, Ansari MA, Khyani IA. Role of mitomycin C in endoscopic management of nasolacrimal duct obstruction. J Dow Uni Health Sci. 2013; 7(2): 63-7

20. Ji Qing-Shan et al. New Mucosal Flap Modification for Endonasal Endoscopic Dacryocystorhinostomy in Asians. International Journal of Ophthalmology 2012; 5(6):704-7

21. Sonkhya N, Mishra P. Endoscopic transnasal dacryocystorhinostomy with nasal mucosal and posterior lacrimal sac flap. J Laryngol Otol. 2009; 123:320-6

22. Sprekelson MB. Endoscopic dacryocystorhinostomy- surgical techniques and results. Laryngoscope 1996; 106:187-9

23. Unlu HH, Toprak B, Aslan A, Guler C. Comparison of surgical outcomes in primary endoscopic dacryocystorhinostomy with and without silicone intubation. Ann Otol Rhinol Laryngol. 2002; 111:704-9

24. Smimov G, Tuomilehto H, Teräsvirta M, Nuutinen J, Seppä J. Silicone tubing after endoscopie dacryocystorhinostomy: is it necessary? Am J Rhinol. 2006; 20:600-2

25. Ray B, Datta D, Roy P. Long Term Success of Endo-DCR with Silicone Tube Catheter (STC) versus Endo-DCR without STC: A Comparative Study. Bengal J Otolaryngol Head Neck Surg. (BJOHNS) 2016; 24(2):88-93

26. Jin HR, Yeon JY, Choi MY. Endoscopic dacryocystorhinostomy: Creation of a large marsupialized lacrimal sac. J Korean Med Sci. 2006; 21:719-23 
27. Zilelioglu G, Tekeli O, Ugurba SH, Akiner M, Akturk T, Anadolu Y. Results of endoscopic endonasal non-laser dacryocystorhinostomy Doc Ophthalmol. 2002; 105:57-62

28. Kim JH, Shin JH, Sony HY, et al. Long-term results and factors affecting patency after removal of nasolacrimal stents. J Vasc Interv Radiol. 2006; 17 (7): 1125-30

29. Farooq MU, Ansari MA. Cerebrspinal fluid rhinorrhea: etiology, site of leakage and endoscopic management. J Coll
Physicians Surg Pak. 2011; 21:460-3

30. Roozitalab MH, Amirahmadi M, Namazi MR. Results of the application of intraoperative Mitomycin C in dacryocystorhinostomy. Eur J Ophthalmology 2004; 14(6):461-3

31. Farahani F, Ramezani A. Effect of intra operative mitomycin C application on recurrence of endoscopic dacryocystorhinostomy. Saudi Med J. 2008; 29 (9): 1354-1356. 